\title{
Roman Machuga
}

Uniwersytet Warmińsko-Mazurski w Olsztynie

e-mail: roman.machuga@gmail.com,roman.machuga@uwm.edu.pl

\section{WYKORZYSTANIE CHMUR OBLICZENIOWYCH W POLSCE I W PAŃSTWACH UNII EUROPEJSKIEJ: ANALIZA PORÓWNAWCZA}

\section{USE OF CLOUD COMPUTING IN POLAND AND IN THE COUNTRIES OF THE EUROPEAN UNION: COMPARATIVE ANALYSIS}

DOI: $10.15611 /$ ie.2017.4.09

JEL Classification: L86

Streszczenie: Celem artykułu jest przeprowadzenie analizy porównawczej obecnego stanu wykorzystania chmur obliczeniowych w Polsce i w państwach Unii Europejskiej oraz określenie możliwych działań dla promowania korzyści i perspektyw ich zastosowania w działalności gospodarczej i życiu społecznym. W artykule przedstawiono najważniejsze korzyści wykorzystania przetwarzania informacji w chmurach obliczeniowych, możliwe kierunki zastosowania chmur obliczeniowych. Dokonano analizy stanu wykorzystania chmur obliczeniowych w Polsce w porównaniu z państwami Unii Europejskiej. Na podstawie przeprowadzonej wieloaspektowej analizy opracowano szczegółowe wnioski, które są uogólnieniem obecnego stanu wykorzystania serwisów wirtualnych. Dodatkowo we wnioskach określono możliwe aktywności zarówno na poziomie państwowym, jak i w środowiskach naukowym oraz naukowo-dydaktycznym w celu popularyzacji chmur obliczeniowych, zwiększenia poziomu ich wykorzystania przez przedsiębiorców i użytkowników indywidualnych.

Słowa kluczowe: chmura obliczeniowa, serwis internetowy, technologie informacyjno-komunikacyjne.

Summary: The aim of the article is to conduct a comparative analysis of the current state of use of cloud computing in Poland and in the countries of the European Union and to identify possible actions to promote the benefits and perspectives of their implementation in various areas of economic activity and social life. The article presents the most important benefits of using information processing in clouds and possible directions of application of cloud computing. An analysis of the state of cloud computing usage in Poland in comparison with the countries of the European Union was made. Based on the multi-aspect analysis, detailed conclusions have been developed that generalize the current state of use of virtual sites. In addition, the conclusions set out possible activities both at the state level as well as in scientific and scientific and didactic environments in order to popularize cloud computing, increase the percentage of their use by entrepreneurs and individual users.

Keywords: cloud computing, internet service, information and communication technologies. 


\section{Wstęp}

W ciągu ostatnich 20 lat ma miejsce szybki rozwój różnych technologii informacyjnych. Obecnie ich zastosowanie poszerza się w różnych obszarach zarówno działalności gospodarczej, jak i życia społecznego. Dzisiaj nowoczesna technika komputerowa oraz technologie informacyjno-komunikacyjne są wykorzystywane w różnych dziedzinach, w tym w gospodarce, administracji, polityce, socjologii, ochronie zdrowia, kulturze, nauce, transporcie, turystyce, edukacji. Wraz z zastosowaniem różnorodnego oprogramowania $\mathrm{w}$ formie aplikacji lokalnych coraz częściej stosowane są programy oraz serwisy dostępne przez Internet.

Dzisiaj, korzystając z usług i oprogramowania internetowego, „w trybie online można prowadzić biznes, składać różne sprawozdania, korzystać z internetowych usług administracyjnych, robić zakupy oraz sprzedawać towar przez Internet, uczyć się za pośrednictwem platform e-learningowych, organizować wirtualne biura, udostępniać różnego rodzaju informację, zbierać informację marketingową" [Machuga 2016a]. Ten wykaz może być dopełniony i innymi działaniami, które mogą być zrealizowane przez Internet. Na przykład przy zastosowaniu technologii internetowych można prowadzić różne badania ankietowe [Machuga 2016b], wyszukiwać i gromadzić dane statystyczne, komunikować się z innymi użytkownikami w sieci komputerowej, pracować w trybie online nad wspólnymi projektami, reklamować towary, korzystać z różnych narzędzi i serwisów udostępnianych przez wirtualne przestrzenie obliczeniowe.

Celem artykułu jest przeprowadzenie analizy porównawczej obecnego stanu wykorzystania chmur obliczeniowych w Polsce i w państwach Unii Europejskiej oraz określenie możliwych działań dla promowania korzyści i perspektyw ich zastosowania w działalności gospodarczej i życiu społecznym.

\section{Technologie chmur obliczeniowych}

Pojęcie chmury obliczeniowej (wirtualnej przestrzeni obliczeniowej czy cloud computing w języku angielskim), ,jest bardzo szerokie i niejednoznaczne - w rozległym znaczeniu przetwarzaniem w chmurze obliczeniowej jest wszystko, co jest przetwarzane poza lokalną zaporą sieciową" [Górecki 2014]. Dzisiaj przez naukowców są stosowane i cytowane w artykułach różne definicje przetwarzania w chmurze obliczeniowej. Najczęściej używane z nich:

- Wirtualna przestrzeń obliczeniowa jest ,usługą polegającą na zdalnym udostępnieniu mocy obliczeniowej urządzeń IT, oferowaną przez zewnętrzne podmioty, dostępną na żądanie w dowolnej chwili oraz skalująca się w miarę zapotrzebowania" [SICD.pl 2014].

- „Chmura obliczeniowa to zewnętrzna, wirtualna przestrzeń, na której zapisywane są dane" [Poradnik Przedsiębiorcy 2016]. 
- „Chmura obliczeniowa to nowoczesny model organizacji pracy przedsiębiorstwa, który polega na korzystaniu z usług dostarczonych przez wybranego, zewnętrznego dostawcę w ramach opłaty licencyjnej. Klienci korzystający z rozwiązań tego typu mają zapewniony szybki dostęp do swoich danych oraz stałą opiekę techniczną dystrybutora" [Poradnik Przedsiębiorcy 2016].

- Chmura obliczeniowa może być traktowana jako „model umożliwiający powszechny, wygodny, udzielany na żądanie dostęp za pośrednictwem sieci do wspólnej puli możliwych do konfiguracji zasobów przetwarzania (np. sieci, serwerów, zasobów przechowywania, aplikacji i usług), które można szybko dostarczyć i uwolnić przy minimalnym wysiłku zarządzania lub działania ze strony usługodawcy" [Dyrekcja Generalna... 2012].

To tylko kilka z istniejących definicji. Ich częścią wspólną jest fakt, że dostęp do różnych usług, oprogramowania, mocy obliczeniowej, przestrzeni dyskowej odbywa się zdalnie (przez Internet). Użytkownikami takich chmur obliczeniowych mogą być zarówno przedsiębiorstwa, jak i osoby prywatne.

Za dobrą próbę zdefiniowania cech podstawowych chmur obliczeniowych i ich modeli można przyjąć standard, który został opracowany i opublikowany w roku 2011 przez Departament Handlu (USA) i Narodowy Instytut Standardów i Technologii [Mell, Grance 2011].

Najważniejsze zalety chmur obliczeniowych:

- klient nie musi instalować na własnych komputerach wybranego oprogramowania;

- aktualizacja oprogramowania odbywa się na serwerze; do korzystania z niego wystarczy tylko podłączenie posiadanego sprzętu komputerowego do sieci internetowej;

- znaczna redukcja kosztów (nie ma potrzeby kupna oprogramowania dla każdego komputera, a parametry ich wydajności mogą być niższe);

- możliwości pracy zdalnej, niezależnie od miejsca lokalizacji pracownika;

- możliwości organizacji „wirtualnego biura” bez konieczności posiadania oddzielnego pomieszczenia oraz obecności wszystkich pracowników w ,jednym miejscu";

- rozwiązanie problemu różnych wersji wspólnych dokumentów, nad którymi ma pracować kilku pracowników, automatyczna aktualizacja wprowadzanych zmian dla wszystkich pracowników;

- szerokie możliwości zarządzania prawami dostępu użytkowników do niezbędnych w pracy informacji, czyli plików;

- ciągłe protokołowanie dostępu do dokumentów oraz totalne zapisywanie wprowadzanych przez użytkowników zmian [Machuga 2016a].

Aktualnie technologie chmur obliczeniowych mogą być wykorzystywane przez różnych użytkowników do:

- zdalnego wykorzystania mocy obliczeniowej komputerów;

- ciągłego gromadzenia informacji i przechowywania plików; 
- użytkowania online oprogramowania (księgowego, biurowego, CRM);

- rozpowszechniania informacji;

- korzystania z poczty elektronicznej;

- hostingu baz danych itd.

Ze względu na pełną uniwersalność technologie chmur obliczeniowych mogą być wykorzystywane przez różnych użytkowników w wielu branżach gospodarki, administracji, życiu społecznym, ale także do celów osobistych. Bez względu na szybki rozwój technologii informacyjnych i informacyjno-komunikacyjnych oraz ich powszechne wdrażanie w życie codzienne zastosowanie chmur obliczeniowych w różnych krajach, zwłaszcza w państwach Unii Europejskiej, odbywa się na różnych poziomach.

\section{Aktualny stan wykorzystania chmur obliczeniowych}

Ze względu na powszechne zastosowanie wirtualizacji oraz zwiększenie znaczenia Internetu w życiu codziennym ważne jest określenie obecnego stopnia rozpowszechniania chmur obliczeniowych wśród różnych użytkowników w Polsce oraz jego porównanie ze średnią w państwach Unii Europejskiej.

Bardzo szczegółowe i dokładne badanie, dotyczące zalet i wad wykorzystania chmur obliczeniowych oraz stanu obecnego, przeprowadzone było przez Parlament Europejski (Dyrekcję Generalną ds. Polityki Wewnętrznej Unii Europejskiej za pośrednictwem Departamentu Tematycznego A: Polityka Gospodarcza i Naukowa), a wyniki tego badania zostały opublikowane i udostępnione na stronie internetowej w roku 2012 [Dyrekcja Generalna... 2012]. Dokładne badanie też zostało przeprowadzone przez Badawczą Służbę Parlamentu Europejskiego, a same wyniki opublikowano w styczniu 2014 roku [Leimbach 2014].

Aby dokonać analizy porównawczej stanu obecnego wykorzystania chmur obliczeniowych w Polsce i w państwach Unii Europejskiej, warto skorzystać z danych udostępnianych przez głównego dostawcę informacji statystycznych w Europie Eurostat ${ }^{1}$. Przy opracowaniu charakterystyki obecnego stanu spraw tylko w Polsce można dodatkowo skorzystać z aktualnej informacji udostępnianej przez Główny Urząd Statystyczny².

Głównymi użytkownikami chmur obliczeniowych są przedsiębiorstwa i osoby prywatne. Jeśli chodzi o użytkowanie usług wirtualnych przestrzeni obliczeniowych przez przedsiębiorstwa, niestety Polska znajduje się blisko końca pośród państw Unii Europejskiej. W roku 2016 przedsiębiorstw, które dokonały zakupu usługi chmur obliczeniowych, było tylko 8\%, podczas gdy średnia w państwach Unii Europejskiej wynosił $21 \%$ (rys. 1). Wprawdzie są również kraje o niższym odsetku, ale warto też zwrócić uwagę na to, że dla Finlandii wskaźnik ten stanowi 57\%.

\footnotetext{
${ }^{1}$ Home - Eurostat, http://ec.europa.eu/eurostat (11.11.2017).

2 Główny Urząd Statystyczny, http://stat.gov.pl/ (11.11.2017).
} 


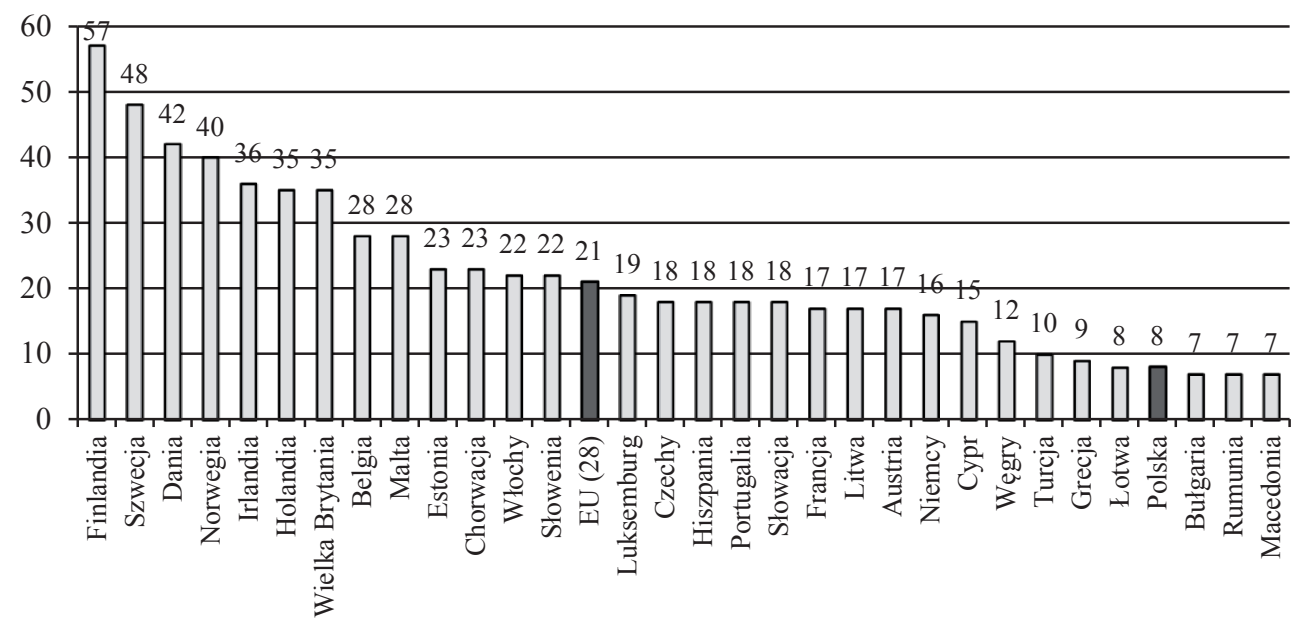

Rys. 1. Odsetek przedsiębiorstw, które kupiły usługi chmur obliczeniowych w roku 2016

Źródło: opracowanie własne na podstawie [Eurostat 2017a; Eurostat 2017b].

Co roku w Polsce odsetek przedsiębiorstw korzystających z chmur obliczeniowych wzrasta (rys. 2). W latach 2014-2016 wzrastał o 1\% rocznie. To pozytywna dynamika, ale nadal niska w porównaniu ze średnią w państwach UE oraz z dynamiką Finlandii (od 51\% do 57\%).

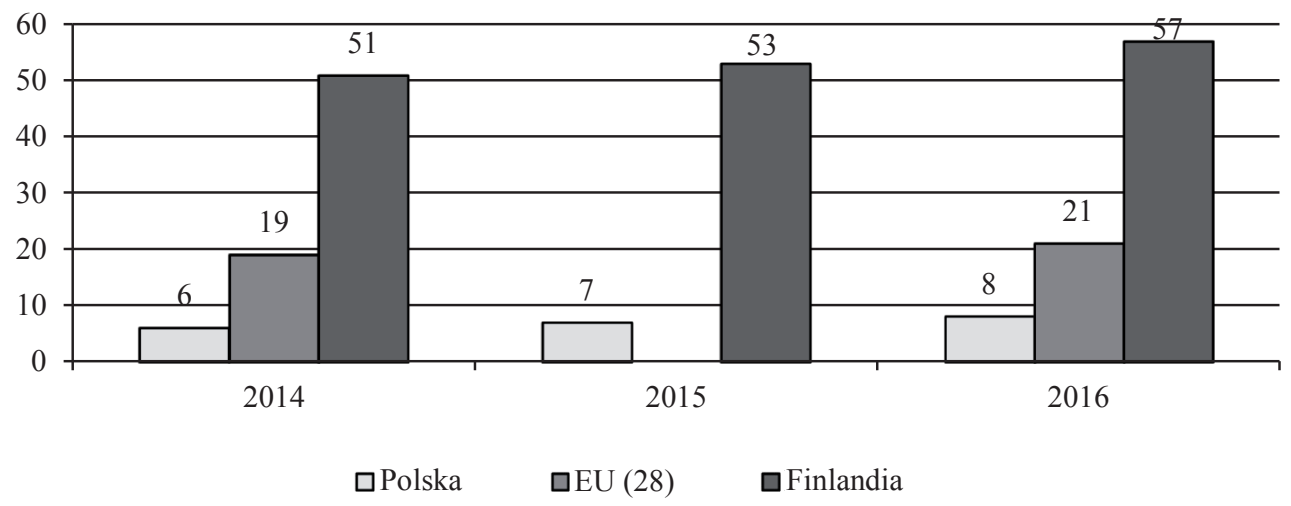

Rys. 2. Dynamika wzrostu odsetka przedsiębiorstw, które nabyły usługi chmur obliczeniowych Źródło: opracowanie własne na podstawie [Eurostat 2017a].

Jeśli chodzi o charakter branży, to 45\% przedsiębiorstw w państwach UE korzystających z usług chmur obliczeniowych pracuje w sferze informacyjno-komunikacyjnej [Eurostat News Release 2014]. Wśród przedsiębiorstw w innych branżach wykorzystanie serwisów w chmurach obliczeniowych niestety jest mniej rozpowszechnione. 
Według najnowszych danych Głównego Urzędu Statystycznego w Polsce odsetek przedsiębiorstw korzystających z usług chmur obliczeniowych w roku 2017 wzrósł już do 10\% [GUS 2017], co też świadczy o pozytywnej dynamice.

Zakres wykorzystania chmur obliczeniowych przez przedsiębiorstwa porównano według pewnych kryteriów (tab. 1).

Tabela 1. Porównanie poziomów wykorzystania chmur obliczeniowych w Polsce, państwach Unii Europejskiej i Finlandii (dane za rok 2016, odsetek przedsiębiorstw)

\begin{tabular}{|l|c|c|c|c|c|c|c|c|c|}
\hline \multirow{2}{*}{\begin{tabular}{l} 
Przedsiębiorstwa, które dokonały \\
\multicolumn{1}{|c|}{ zakupu: }
\end{tabular}} & \multicolumn{3}{c|}{ Polska } & \multicolumn{3}{c|}{ UE (28) } & \multicolumn{3}{c|}{ Finlandia } \\
\cline { 2 - 12 } & 2014 & 2015 & 2016 & 2014 & 2015 & 2016 & 2014 & 2015 & 2016 \\
\hline usługi poczty elektronicznej & 4 & 5 & 6 & 12 & - & 14 & 33 & 37 & 42 \\
\hline $\begin{array}{l}\text { usługi oprogramowania biurowego } \\
\text { online }\end{array}$ & 2 & 2 & 3 & 6 & - & 9 & 20 & 24 & 29 \\
\hline $\begin{array}{l}\text { usługi hostingowej dla swoich } \\
\text { baz danych }\end{array}$ & 2 & 3 & 4 & 7 & - & 9 & 19 & 23 & 25 \\
\hline $\begin{array}{l}\text { usługi przechowywania plików } \\
\text { w chmurze obliczeniowej }\end{array}$ & 3 & 4 & 5 & 10 & - & 13 & 27 & 30 & 36 \\
\hline $\begin{array}{l}\text { aplikacji finansowych lub księgo- } \\
\text { wych w chmurze obliczeniowej }\end{array}$ & 2 & 2 & 2 & 6 & - & 7 & 20 & 24 & 26 \\
\hline $\begin{array}{l}\text { oprogramowania do zarządzania } \\
\text { relacjami z klientami }\end{array}$ & 1 & 2 & 2 & 4 & - & 6 & 15 & 16 & 20 \\
\hline
\end{tabular}

Źródło: opracowanie własne na podstawie [GUS 2017].

Analiza danych zawartych w tab. 1 pokazuje, że w Polsce poziom wykorzystania chmur obliczeniowych w przedsiębiorstwach jest od 2,3 do 3,5 razy niższy w porównaniu ze średnią w państwach UE. A jeśli porównywać z krajem o najwyższym poziomie rozwoju, to jest Finlandią, wówczas należy stwierdzić, że poziom ten jest niższy od 6,2 do 13,0 razy.

Warto tu zwrócić uwagę, że najbardziej popularnymi usługami, z których korzystają przedsiębiorstwa, jest poczta elektroniczna oraz przechowywanie plików w chmurze obliczeniowej. Taka tendencja jest charakterystyczna zarówno dla Polski, jak i dla państw UE. Różnica polega tylko na tym, że w Finlandii z usług poczty elektronicznej w chmurze obliczeniowej w roku 2016 korzystało 42\% przedsiębiorstw, średnia dla państw UE wynosi $14 \%$, a w Polsce jest to tylko $6 \%$.

Co może być przyczyną takiego stanu? Jakie są powody takiego ograniczenia wykorzystania chmur obliczeniowych przez przedsiębiorstwa?

W grudniu 2016 roku Eurostat opublikował artykuł Cloud computing - statistics on the use by enterprises [Giannakouris, Smihily 2016], w którym przedstawiono wyniki badań ankietowych przedsiębiorstw z roku 2014. Główne problemy przedsiębiorców w tym obszarze to:

- ryzyko naruszenia bezpieczeństwa (duże przedsiębiorstwa - 57\%, małe i średnie $-38 \%)$ 
- niepewność co do obowiązującego prawa, jurysdykcji, mechanizmu rozstrzygania sporów (46\% i 31\%);

- niepewność dotycząca lokalizacji danych (46\% i 29\%);

- problemy z dostępem do danych lub oprogramowania (35\% i 27\%);

- trudności ze zmianą dostawcy usług (34\% i 27\%);

- wysokie koszty zakupu usług przetwarzania w chmurze obliczeniowej (32\% i 32\%);

- niewystarczająca znajomość chmury obliczeniowej (17\% i 32\%).

$\mathrm{Z}$ przedstawionych danych wynika, że najwięcej obaw dotyczących zastosowania chmur obliczeniowych w przedsiębiorstwach związanych jest $\mathrm{z}$ kwestią bezpieczeństwa danych oraz kwestia prawną.

Popularność wirtualnych przestrzeni obliczeniowych wśród użytkowników indywidualnych jest $\mathrm{w}$ pewnym stopniu wyższa $\mathrm{w}$ porównaniu z przedsiębiorstwami.

Pośród użytkowników indywidualnych $16 \%$ korzysta z usług chmur obliczeniowych (rys. 3). Dla państw UE wskaźnik ten stanowi 26\%, w krajach najbardziej rozwiniętych zaś - w Szwecji i Norwegii - z takich usług korzysta aż 46\% użytkowników indywidualnych. Wśród wszystkich państw Unii Europejskiej Polska w tym wykazie niestety znajduje się na przedostatnim miejscu.

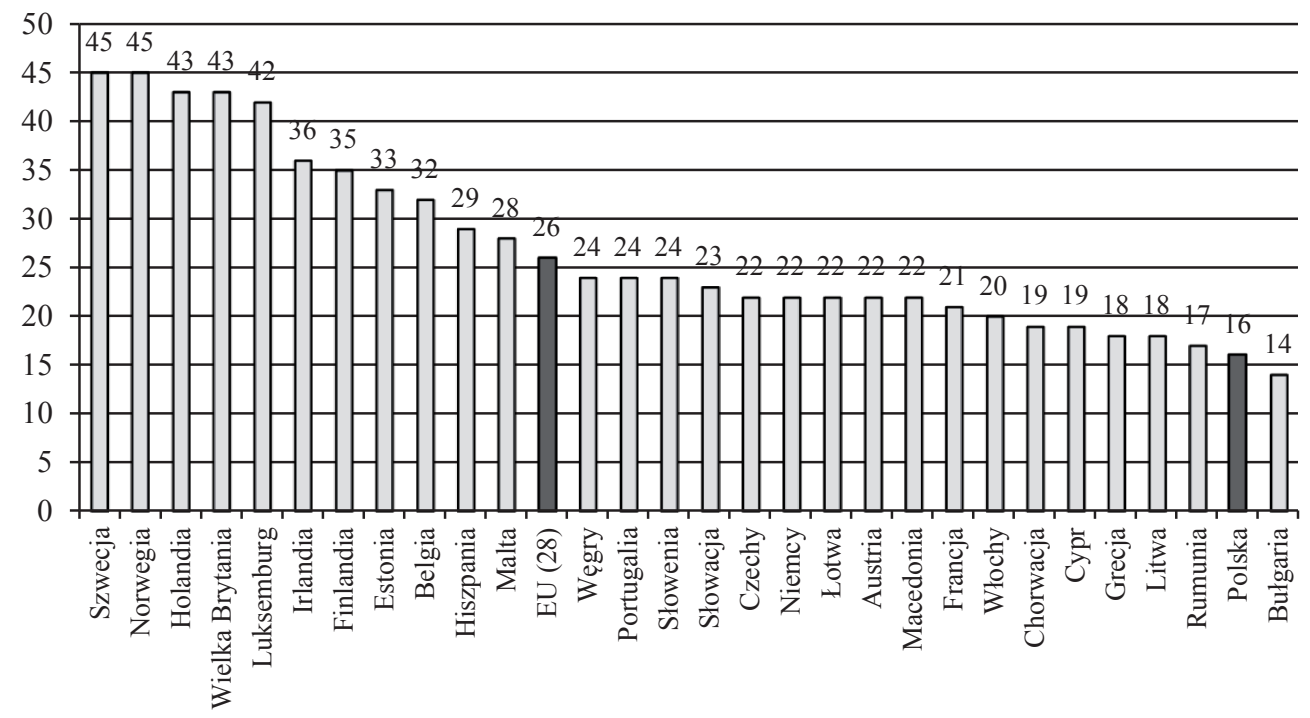

Rys. 3. Wykorzystanie wirtualnej przestrzeni dyskowej do przechowywania plików w roku 2016 (odsetek użytkowników indywidualnych)

Źródło: opracowanie własne na podstawie [Eurostat 2017c].

Obecnie można obserwować bardzo pozytywną dynamikę odsetka polskich użytkowników indywidualnych korzystających z chmur obliczeniowych: w ciągu trzech lat (od roku 2014 do roku 2016) wzrósł on dwukrotnie - z 8\% do 16\% rys. 4). 


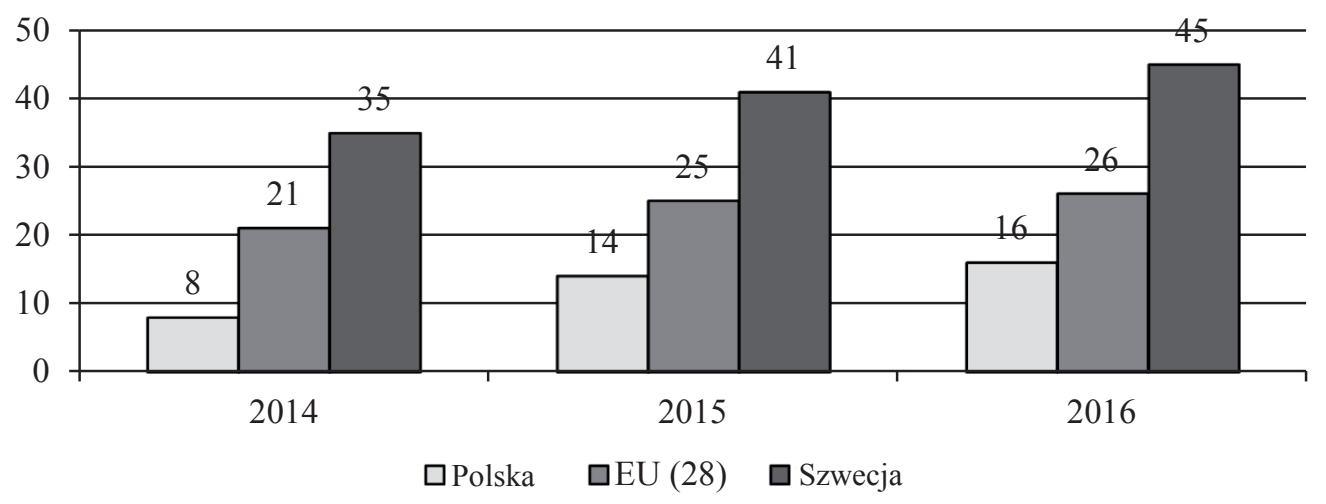

Rys. 4. Dynamika wzrostu odsetka użytkowników indywidualnych, którzy korzystają z wirtualnej przestrzeni dyskowej do przechowywania plików

Źródło: opracowanie własne na podstawie [Eurostat 2017c].

Z punktu widzenia użytkowników indywidualnych istnieją pewne obawy i ograniczenia w korzystaniu z usług chmur obliczeniowych. Wśród nich znajdują się:

- niska prędkość dostępu lub użytkowania Internetu (państwa UE - 8\%, Polska $3 \%)$;

- niezgodność pomiędzy różnymi urządzeniami lub formatami plików (5\% i 1\%);

- problemy z serwerem technicznym, na przykład niedostępność usługi (5\% i 1\%);

- ujawnianie danych stronom trzecim z powodu problemów lub naruszenia bezpieczeństwa (1\% i $0 \%)$;

- nieautoryzowane wykorzystanie danych osobowych przez usługodawcę (1\% i $0 \%$;

- ujawnienie danych stronom trzecim w wyniku problemów z bezpieczeństwem lub naruszenia i nieuprawnionego wykorzystania danych osobowych przez usługodawcę ( $1 \%$ i $0 \%)$;

- niejednoznaczne lub trudne do zrozumienia warunki świadczenia usług (3\% i $1 \%$ );

- trudności w przenoszeniu plików między usługodawcami (2\% i $0 \%)$;

- nie napotkano żadnych problemów (9\% i 5\%) [Eurostat 2017d].

Czy jest możliwy dalszy wzrost odsetka użytkowników korzystających z usług chmur obliczeniowych? Tak, jest możliwy. Tylko najpierw warto zmienić wiedzę użytkowników indywidualnych o chmurach obliczeniowych. Według danych statystycznych w roku 2014 wśród osób korzystających z Internetu w państwach Unii Europejskiej było $29 \%$ wiedzących i $26 \%$ niewiedzących o istnieniu usług chmur obliczeniowych (rys. 5). Natomiast w Polsce liczby te stanowią 22\% wiedzących i niestety aż 36\% niewiedzących. To znaczy, że w Polsce wśród aktywnych użytkowników Internetu co najmniej jedna trzecia z nich nie wie o istnieniu takich serwisów, ich możliwościach oraz przewidywanych korzyściach. 


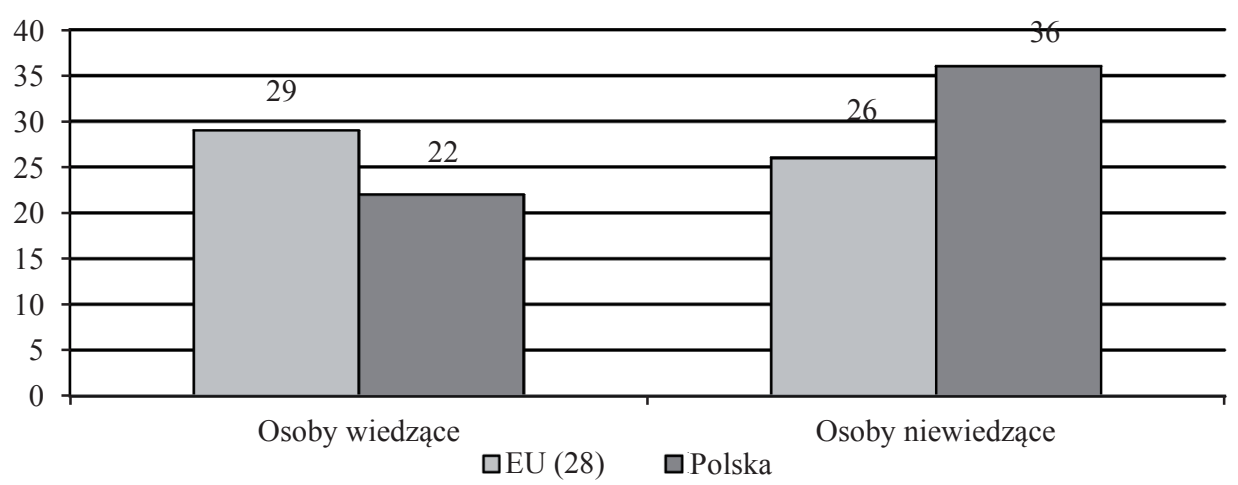

Rys. 5. Osoby wiedzące/niewiedzące o istnieniu usług zapewniających przestrzeń dyskową w Internecie (w roku 2014, odsetek użytkowników indywidualnych)

Źródło: opracowanie własne na podstawie [Eurostat 2017f].

Dlatego żeby można było dodatkowo porównać dane dotyczące Polski (rys. 5) z państwami, które mają najwyższe i najniższe odsetki wiedzących/niewiedzących użytkowników, warto wymienić następujące:

- jeśli chodzi o osoby korzystające z Internetu i wiedzące o istnieniu serwisów w chmurach obliczeniowych, najwyższy notowany jest w Luksemburgu (42\%), a najniższy w Macedonii (8\%);

- co do osób korzystających z Internetu i niewiedzących o istnieniu serwisów w chmurach obliczeniowych najwyższy procent ma Macedonia (48\%), a najniższy odsetek - Norwegia (13\%).

Najważniejszymi powodami nieużywania chmur obliczeniowych wśród wiedzących użytkowników indywidualnych są:

- zapisywanie plików na własnych urządzeniach, koncie e-mail lub rzadko/nigdy niezapisywanie plików (państwa UE - 19\%, Polska - 12\%);

- udostępnianie plików w inny sposób lub w ogóle nieudostępnianie plików online innym osobom (12\% i 7\%);

- brak wiedzy na temat korzystania z takiej przestrzeni dyskowej (7\% i 2\%);

- obawy dotyczące bezpieczeństwa lub prywatności (13\% i 6\%);

- obawy dotyczące niezawodności usługodawców (8\% i 2\%) [Eurostat 2017f].

Wśród wyżej wymienionych powodów nieużywania chmur obliczeniowych najwyższy procent stanowi zapisywanie plików na własnych urządzeniach oraz nieudostępnianie informacji przez Internet. Oba można oznaczyć pojęciem ,podejścia konserwatywnego" w wyborze sposobów przechowywania i rozpowszechniania informacji.

\section{Badania naukowe w obszarze chmur obliczeniowych}

Promocji i rozpowszechnianiu wiedzy o chmurach obliczeniowych służy Program Operacyjny Polska Cyfrowa na lata 2014-2020 [Polska Cyfrowa 2017] (POPC), który został opracowany na podstawie Europejskiej Agendy Cyfrowej [Maciejewski 
i in. 2017] (EAC). Po zmianach z grudnia 2012 roku EAC zawiera 7 obszarów priorytetowych:

1. Europejska gospodarka bez granic - jednolity rynek cyfrowy.

2. Przyśpieszenie innowacji w sektorze publicznym.

3. Bardzo szybki Internet - popyt i podaż.

4. Chmura obliczeniowa.

5. Zaufanie i bezpieczeństwo.

6. Przedsiębiorczość oraz cyfrowe miejsca pracy i umiejętności.

7. Poza sferą badań, rozwoju technologicznego i innowacji: Program działań przemysłowych na rzecz kluczowych technologii wspomagających [Polska Cyfrowa 2017, s. 4].

W wymienionych obszarach wyraźnie wskazano „chmurę obliczeniową”. A dla POPC wyżej wymienione obszary stanowią niestety tylko układ odniesienia. Zostały one zreinterpretowane $\mathrm{w}$ świetle specyficznych potrzeb i uwarunkowań Polski, zwłaszcza: dostęp do szybkiego Internetu (odpowiadający obszarowi 3 z przeglądu EAC); e-usługi publiczne (odpowiadają obszarowi 2 oraz częściowo obszarom 4 i 5 z przeglądu EAC); kompetencje cyfrowe (wpisują się w obszary 5 i 6 z przeglądu EAC, adresując społeczne problemy z wykorzystywaniem TIK wynikające z braku zaufania, umiejętności i świadomości korzyści) [Polska Cyfrowa 2017]. A to znaczy, że Polska nie traktuje rozwoju chmur obliczeniowych i ich zastosowania w życiu społecznym jako zadanie priorytetowe. Wykorzystanie chmur obliczeniowych rozpatruje się tylko w zakresie rozwoju administracji elektronicznej. Na temat perspektyw i sposobów wykorzystania w polskiej administracji publicznej chmur obliczeniowych został przygotowany w roku 2014 przez firmę KMPG w Polsce ${ }^{3}$ specjalistyczny raport [Karasek 2014], w którym opisano światowe trendy oraz uzasadniono korzyści administracji z wdrażania przetwarzania w chmurach obliczeniowych.

Istnieje sporo różnych publikacji i badań naukowych dotyczących chmur obliczeniowych, zwłaszcza perspektyw ich rozwoju i możliwości zastosowania w różnych branżach gospodarki narodowej, rozwoju chmur obliczeniowych z perspektywy zmian technologii informacyjnych w ogóle [Hejduk, Sokolnicki 2017], światowych trendów chmur obliczeniowych [Weins 2017], wykorzystania wirtualnych przestrzeni obliczeniowych dla unifikacji komunikowania [Palonka, Porębska-Miąc 2014] itd.

Dowodem perspektywiczności wykorzystania chmur obliczeniowych jest także to, iż w ostatnich latach Komisja Europejska zwraca coraz większą uwagę na finansowanie badań naukowych w tym zakresie. Zwłaszcza jeśli chodzi o finansowanie projektów i grantów badawczych w ramach Horizon 2020. Na stronie internetowej „Work Programme”4 opublikowano główne programy pracy na lata 2014-2020. Wśród wielu podprogramów warto zwrócić uwagę na „,5.i. Information and Commu-

${ }^{3}$ https://home.kpmg.com/pl/pl/home.html (18.11.2017).

${ }^{4} \mathrm{https} / /$ ec.europa.eu/research/participants/portal/desktop/en/funding/reference_docs.html\# h2020-work-programmes. 
nication Technologies”, który w różnych latach zawiera różne sekcje: w „Work Programme 2014-2015” [European Commission 2015] wpisana jest sekcja „ICT 7 2014: Advanced Cloud Infrastructures and Services”, w „Work Programme 2016-2017" [European Commission 2017a] - sekcja „ICT-06-2016: Cloud Computing”, a w „Work Programme 2018-2020” [European Commission 2017b] - sekcja „ICT-15-2019-2020: Cloud Computing”. Takie wyróżnienie chmur obliczeniowych udowodnia znaczne zainteresowanie i perspektywiczność wskazanego kierunku związanego z przetwarzaniem informacji w chmurach obliczeniowych.

Na programy badawcze w latach 2018-2020 Komisja Europejska w sekcji ICT (Information and Communication Technologies) zaplanowała ogółem ponad 1,8 miliarda euro, przede wszystkim 514 milionów euro na rok 2018 oraz 688 milionów euro na rok 2019. Dodatkowo zarezerwowano 625 milionów euro na rok 2020 na zakończenie wcześniej rozpoczętych badań [European Commission 2017b, s. 136]. Tak znaczne koszty przeznaczone na realizację badań naukowych są potwierdzeniem dynamicznego rozwoju technologii informacyjnych (w tym chmur obliczeniowych) oraz priorytetowości wspomnianego obszaru w państwach Unii Europejskiej.

\section{Wnioski}

Na podstawie powyżej przeprowadzonej wieloaspektowej analizy można wyciągnąć następujące wnioski:

- wykorzystanie chmur obliczeniowych stwarza niewątpliwe korzyści dla przedsiębiorców, administracji publicznej i użytkowników indywidualnych;

- poziom wykorzystania chmur obliczeniowych przez polskie przedsiębiorstwa jest znacznie niższy od średniej w państwach Unii Europejskiej;

- głównymi powodami niewykorzystania wirtualnych przestrzeni obliczeniowych są kwestie bezpieczeństwa danych oraz kwestie prawne;

- wśród polskich użytkowników indywidualnych poziom wykorzystania technologii chmur obliczeniowych jest wyższy od przedsiębiorstw, ale też znacznie niższy od średniej w państwach UE;

- głównymi powodami nieużywania serwisów chmur obliczeniowych przez użytkowników indywidualnych jest brak wiedzy na temat ich istnienia oraz możliwości wykorzystania takich usług;

- w ciągu ostatnich trzech lat zaobserwowano pozytywną dynamikę wzrostu w Polsce użytkowania chmur obliczeniowych przez przedsiębiorstwa i osoby indywidualne;

- zwiększenie wykorzystania w Polsce serwisów chmur obliczeniowych możliwe jest przez ciągłą ich popularyzację zarówno na poziomie państwowym, jak i przy aktywnym udziale środowiska naukowego.

W celu popularyzacji chmur obliczeniowych, zwiększenia poziomu ich wykorzystania przez przedsiębiorców i użytkowników indywidualnych można zaproponować następujące aktywności: 
1) na poziomie państwowym:

- opracowanie i wniesienie zmian w obowiązujący „Program Operacyjny Polska Cyfrowa na lata 2014-2020" lub założenie w kolejnym programie społecznego zadania priorytetowego dotyczącego rozwoju chmur obliczeniowych;

- nowelizacja obowiązujących aktów prawnych w celu ułatwienia i zachęcania do wdrażania przetwarzania informacji w chmurach obliczeniowych zarówno przez przedsiębiorców w procesie biznesowym, jak i przez administrację publiczną $\mathrm{w}$ relacjach z interesariuszami;

- zwiększenie finansowania badań naukowych w obszarze ICT, zwłaszcza dotyczących wirtualnych przestrzeni obliczeniowych;

2) w środowisku naukowym:

- popularyzacja korzyści wykorzystania chmur obliczeniowych przez przedsiębiorców i użytkowników indywidualnych w formie wystąpień na konferencjach, publikacji artykułów naukowych i popularnonaukowych;

- realizacja badań naukowych dotyczących użytkowania chmur obliczeniowych, ich zastosowania w różnych branżach gospodarki narodowej oraz życia społecznego;

3) w środowisku naukowo-dydaktycznym:

- wprowadzenie w procesie edukacyjnym przedmiotów związanych z wykorzystaniem technologii informacyjno-komunikacyjnych w ogóle, a zwłaszcza chmur obliczeniowych. Takimi przedmiotami mogą być na przykład, technologie informacyjno-komunikacyjne, zarządzanie informacjami przez chmury obliczeniowe itp.

\section{Literatura}

Dyrekcja Generalna ds. Polityki Wewnętrznej Unii Europejskiej, 2012, Chmury obliczeniowe. Ekspertyza. Wydawca: Dyrekcja Generalna ds. Polityki Wewnętrznej Unii Europejskiej, Departament Tematyczny A: Polityka Gospodarcza i Naukowa, http://www.europarl.europa.eu/RegData/etudes/etudes/join/2012/475104/IPOL-IMCO_ET(2012)475104_PL.pdf(11.11.2017).

European Commission, 2015, Horizon 2020. Work Programme 2014-2015, http://ec.europa.eu/research/participants/data/ref/h2020/wp/2014_2015/main/h2020-wp1415-leit-ict_en.pdf (18.11.2017).

European Commission, 2017a, Horizon 2020. Work Programme 2016-2017, http://ec.europa.eu/research/participants/data/ref/h2020/wp/2016_2017/main/h2020-wp1617-leit-ict_en.pdf (18.11.2017).

European Commission, 2017b, Horizon 2020. Work Programme 2018-2020, http://ec.europa.eu/research/participants/data/ref/h2020/wp/2018-2020/main/h2020-wp1820-leit-ict_en.pdf (18.11.2017).

Eurostat, 2017a, Cloud computing services, http://appsso.eurostat.ec.europa.eu/nui/show.do?dataset=isoc_cicce_use\&lang=en (11.11.2017).

Eurostat, 2017b, Cloud Computing Use in EU Enterprises, http://ec.europa.eu/eurostat/en/web/products-eurostat-news/-/DDN-20170330-1, (11.11.2017).

Eurostat, 2017c, Individuals - Use of Cloud Services, http://appsso.eurostat.ec.europa.eu/nui/show. do?dataset=isoc_cicci_use\&lang=en (11.11.2017). 
Eurostat, 2017d, Problems Experienced When Using Cloud Services, http://appsso.eurostat.ec.europa. eu/nui/show.do?dataset=isoc_cicci_pb\&lang=en (15.11.2017).

Eurostat, 2017e, Use of Cloud Services, http://ec.europa.eu/eurostat/en/web/products-eurostat-news/-/ DDN-20170803-1 (11.11.2017).

Eurostat, 2017f, Awareness about Cloud Services and Reasons for Non-Use, http://appsso.eurostat. ec.europa.eu/nui/show.do?dataset=isoc_cicci_awobs\&lang=en (15.11.2017).

Eurostat News Release, 2014, Cloud Computing Services Used by One Out of Every Five Enterprises in the EU28, http://ec.europa.eu/eurostat/documents/2995521/6208098/4-09122014-AP-EN.pdf/627ddf4f-730a-46ca-856b-32532d8325c5 (15.11.2017).

Giannakouris K., Smihily M., 2016, Cloud Computing - Statistics on the Use by Enterprises, http:// ec.europa.eu/eurostat/statistics-explained/index.php/Cloud_computing_-_statistics_on_the_use_ by_enterprises\#Factors_preventing_enterprises_from_using_cloud_computing_.282014_survey.29 (15.11.2017).

Górecki P., 2014, Czym jest chmura obliczeniowa i „cloud computing”?, https://www.tabletowo. p1/2014/08/27/czym-jest-chmura-obliczeniowa-i-cloud-computing/ (11.11.2017).

GUS, 2017, Spoleczeństwo informacyjne w Polsce w 2017 r., Główny Urząd Statystyczny, Warszawa, http://stat.gov.pl/files/gfx/portalinformacyjny/pl/defaultaktualnosci/5497/2/7/1/spoleczenstwo_informacyjne_w_polsce_w_2017.pdf (11.11.2017).

Hejduk I., Sokolnicki J., 2017, Cloud computing z perspektywy zmian nowych technologii informacyjnych, Roczniki Kolegium Analiz Ekonomicznych, Szkoła Główna Handlowa w Warszawie, Warszawa, zeszyt 45/2017, s. 13-32.

Karasek J., 2014, Raport: sposób wykorzystania chmury w polskiej administracji, http://itwiz.pl/raportsposob-wykorzystania-chmury-polskiej-administracji/ (18.11.2017).

Leimbach T., 2014, Potential and Impacts of Cloud Computing Services and Social Network Websites. Science and Technology Options Assessment, http://www.europarl.europa.eu/RegData/etudes/ etudes/join/2014/513546/IPOL-JOIN_ET(2014)513546_EN.pdf(11.11.2017).

Machuga R., 2016a, Możliwości zarządzania informacjami przez wirtualne przestrzenie obliczeniowe, [w:] Powiązania organizacyjne w społeczeństwie sieciowym, red. E. Skrzypek, G. Grela, M. Hofman, Katedra Zarządzania Jakością i Wiedzą, Lublin, s. 179-186.

Machuga R., 2016b, Nowoczesne technologie informacyjno-komunikacyjne stosowane $w$ badaniach ankietowych prowadzonych $w$ szkolnictwie wyższm, [w:] Zarzadzanie w szkolnictwie wyższym i innowacje w gospodarce, red. T. Wawak, Wydawnictwo Uniwersytetu Jagiellońskiego, Kraków, s. 203-211.

Maciejewski M., Dancourt L., Marschall B., 2017, Europejska Agenda Cyfrowa, http://www.europarl. europa.eu/ftu/pdf/pl/FTU 5.9.3.pdf (16.11.2017).

Mell P., Grance T., 2011, The NIST Definition of Cloud Computing, http://csrc.nist.gov/publications/ nistpubs/800-145/SP800-145.pdf (11.11.2017).

Palonka J., Porębska-Miąc T., 2014, Cloud computing and mobility as the main trends in unified communications, Ambient Technology and Creativity Support Systems, Katowice, s. 119-134.

Polska Cyfrowa, 2017, Program Operacyjny Polska Cyfrowa na lata 2014-2020, https://www.polskacyfrowa.gov.pl/strony/o-programie/dokumenty/program-polska-cyfrowa-2014-2020/ (16.11.2017).

Poradnik Przedsiębiorcy, 2016, Przedsiębiorca w chmurze obliczeniowej, http://poradnik.wfirma.pl/-przedsiebiorca-w-chmurze-obliczeniowej (11.11.2017).

SICD.pl, 2014, Chmura obliczeniowa - definicja, rodzaje $i$ warstwy, http://sicd.pl/teoria/chmura-obliczeniowa/ (11.11.2017).

Weins K., 2017, Cloud Computing Trends: 2017 State of the Cloud Survey, https:/www.rightscale.com/ blog/cloud-industry-insights/cloud-computing-trends-2017-state-cloud-survey (18.11.2017). 